\title{
Animal Rights Terrorists: What Every Neuroscientist Should Know
}

\author{
Jeffrey H. Kordower \\ Chairman, Committee for Use of Animals in Research, Society for Neuroscience \\ Department of Neurological Sciences and Research Center for Brain Repair, Rush University Medical Center, Chicago, Illinois 60612
}

\section{Introduction}

The disgraceful, illegal, and immoral tactics used by animal rights activists to forward their agenda have led to the federal government labeling them as domestic terrorists, a very well deserved categorical name. The types of terrorism engendered by these groups are varied, but most recently their most violent and troublesome acts have occurred at the homes of neuroscientists. Drs. Ringach and Jentsch have detailed many of these terrorist attacks in their accompanying commentary, and I will not review them here. However, do not let the preponderance of violent animal rights activity occurring in California mislead you into thinking that Society for Neuroscience (SfN) members in other states are immune to the situation. These violent acts occur across the country, with researchers in Utah, Connecticut, Oregon, as well as numerous other locales having reported violent attacks at their homes, often in the presence of children. Let us also be clear about the individuals whom they are attacking. These scientists have not just been performing research on animals: all have been performing responsible research on animals, using procedures that have been approved by the National Institutes of Health (NIH) and the Institutional Animal Care and Use Committees (IACUC) of their universities.

While these activists' strategy of terrorizing investigators and their families at their homes may be relatively new, these actions and their intent to terrorize are not. The origin of animal rights activism

Received Aug. 3, 2009; accepted Aug. 5, 2009.

Correspondence should be addressed to Dr. Jeffrey H. Kordower, Department of Neurological Sciences, Rush University Medical Center, 1735 West Harrison Street, Chicago, IL60612. E-mail: jkordowe@rush.edu.

DOI:10.1523/JNEUROSCI.3764-09.2009

Copyright $\odot 2009$ Society for Neuroscience $\quad$ 0270-6474/09/2911419-02\$15.00/0 can be traced to the publication of Animal Liberation in 1975 by Philosophy Professor Peter Singer. Singer is now viewed as the father of the modern animal rights movement. In 1981, Alex Pacheco and Ingrid Newkirk formed People for the Ethical Treatment of Animals (PETA) in Washington, DC. These two events catapulted animal rights activism into the popular public mindset. While their misguided message about the responsible use of animals in research was heard, their methods of operation received less attention. They fully support the burning down of laboratories. Indeed, Newkirk has been quoted as saying so on numerous occasions (see http://www.activistcash. com/biography_quotes.cfm/bid/456). The Animal Liberation Front (ALF) sets fire to mink farms at Oregon State and Michigan State Universities. Other groups, such as Stop Huntingdon Animal Cruelty (SHAC) attacked the Huntingdon Life Sciences and its shareholders. The company and its shareholders were completely unaware of the reason they were attacked (they provided loans for companies performing animal research), and the company nearly collapsed financially. In 2000, ALF stole dozens of research animals from laboratories at the University of Minnesota, and in 2004, they broke into University of Iowa laboratories, causing hundreds of thousands of dollars in damages. These and other groups also disrupt science by using legal, but harassing, methods such as a continuous flurry of Freedom of Information Act (FOIA) requests and IACUC misconduct claims, most of which have been found to be completely baseless after costly investigation. Other efforts include legal maneuvers to grant animals "personage," or legal rights equal to humans, and combating even noninvasive research using great apes (which, incidentally, is the only genus that can be effectively used to model human hepatitis $\mathrm{C}$ infection). These are just a few of the numerous activities of these groups over the past three decades.

So, with their widespread and dangerous activities, why has our membership been relatively silent on this matter? It is difficult to say, but one theory is that these activities have been predominantly directed against researchers using nonhuman primates and companion animals, the small minority of SfN members. The majority of members perform research on rodents, and they might conclude that this is "not my problem." Wrong! The violent activities of these animal rights activists are no longer exclusive to researchers that work with unusual species: a number of researchers who work with rodents have recently been targeted and attacked with the same violence and vigor as their colleagues. Now, everyone is at risk and a strong outcry by our membership is needed.

So, what should researchers and SfN members do? The first part is easy. Go to http://www.ucla-pro-test.org/. This is a website created by University of California, Los Angeles (UCLA) faculty in a stand against the animal rights terrorists. Sign the petition at www.raisingvoices.net, take a stand against these violent criminals, and take a stand for the responsible use of animals in research. Second, download the Best Practices document from the SfN website. This is a document that has been created and vetted by the Committee for the Use of Animals in Research (CAR) at SfN, a committee I am honored to chair. This document is based upon the UCLA Task Force document that was created following a series of violent attacks 
on their faculty. While the University of California system might be properly criticized for initially moving slowly on this front, they have become welcome leaders and champions for their embattled faculty, and all SfN members should be grateful for their generosity in sharing their taskforce findings with us. The document is meant for any researcher to take to their university leadership to serve as a plan for protecting researchers under attack. It should be presented before any attack or threat of attack occurs. This document is not specific for animal rights issues and would prove valuable for researchers under attack for any reason (e.g., use of human fetal tissue or human embryonic stem cells in research). The document is divided into three parts and a summary of its concepts are detailed below:

\section{Part 1: Leadership and administration}

University leaders should provide regular, explicit public affirmation from the institutional leadership in support of academic freedom and state the institutional commitment to ensuring the protection of those individuals exercising it. In cases in which researchers are under attack, the university should pursue legal measures, public declarations, statements of support, and provisions of accurate information to the public and other forms of sustaining moral and psychological support. When illegal activities occur, university leadership should publicly support and encourage prosecution to the fullest extent of the law. Additionally, the university should request formal support from the academic senate or equivalent body.

\section{Part 2: Security}

The university should assign staff to monitor security efforts, deploy campus resources as necessary, and communicate with affected researchers. It should ensure that these personnel are on call at all times and have the ability to easily communicate with top administration officials. The university should develop a plan with local law enforcement. The university should develop a formal process for responding to threats against personal and physical safety.

The university should establish an organizational structure that anticipates and forestalls threats to a researcher. The university should establish or strengthen security protocols. The university should ensure regular and effective communications between security personnel and community law enforcement to avoid gaps in protection.

\section{Part 3: Communication and advocacy}

The university should actively pursue the introduction and passage of federal, state, and local legislation and regulations that would protect research. They should urge lawmakers to ensure consistency of protective coverage across jurisdictions. They should proactively build relationships with reporters to convey accurate information about responsible research, as well as specific research being conducted at the facility, and they should regularly examine studentuniversity organizations, in keeping with standards of protected activity.

I have taken this document to my administration, it was well received, and it has been adopted. I and my colleagues are safer because of it.

The CAR committee at $\mathrm{SfN}$ as well as the National Association for Biomedical Research (NABR) are also important resources for individuals who are under attack. Indeed, the CAR committee should be informed of all animal rights activist attacks, and the committee Chair and the SfN staff will provide as much assistance as possible. Additionally, it is imperative that we educate the public on the appropriateness of responsible research using animals, and on the health benefits they have provided both humans and nonhumans. Talking points for these concepts can be found at the SfN website.

Finally, I and many of my colleagues have been greatly disappointed by the failure of NIH to take a stronger stand against animal rights terrorists. Articles have been written by high-ranking $\mathrm{NIH}$ officials condemning their activities; e.g., http:// www.nih.gov/about/director/02082008_ statement_UCLAresearcher.htm. That is good. However, it remains hard to imagine how words alone will have any material impact on the behavior of these criminals. The leadership of SfN, including CAR members like myself, have solicited NIH to mandate that all custodians of their research funds (i.e., virtually all universities and other institutions performing research) have a protection plan in place for their researchers. Common sense would seem to dictate that if $\mathrm{NIH}$ can mandate the existence of IACUC, Institutional Review Board (IRB), and other oversight committees to protect animals and clinical trial patients before receiving $\mathrm{NIH}$ funding, a similar requirement can be instituted for the protection of the individuals performing the research. The Best Practices document described above can serve as a template for such a plan. This request has fallen on deaf ears. Hopefully, with the appointment of a new director of $\mathrm{NIH}$, we will be able to readdress this issue in the near future with greater success.

In summary, as individual scientists I urge you to be proactive, be concerned, and be a loud voice for the responsible use of animals in research and be completely intolerant of criminals' intent on preventing the honest performance of our important work. 